\title{
SOCIAL JUSTICE AND HUMAN RIGHTS IN EDUCATION POLICY DISCOURSE: ASSESSING NELSON MANDELA'S LEGACY
}

\author{
Abrehet Gebremedhin \\ University of Denver \\ Email: abrehet.gebremedhin@gmail.com
}

\section{Devin Joshi}

Singapore Management University

Email: devinjoshi@smu.edu.sg

\section{ABSTRACT}

Twenty years after South Africa's democratisation, Nelson Mandela's passing has prompted scholars to examine his legacy in various domains. Here we take a look at his legacy in education discourse. Tracing Mandela's thoughts and pronouncements on education we find two major emphases: a view of education as a practical means to economic development, and education as a means to social justice, human rights, and democracy. Assessing the legacy of these twin emphases, we conducted qualitative and quantitative content analysis of turning point documents in education policy and annual reports from the respective South African ministries of education over the last two decades. Our analysis reveals that although a focus on education policy for economic development has consistently remained strong, Mandela's view of education serving to foster social justice, inter-racial equality, human rights, and a deepening of democracy has faded from official educational policy discourse.

Keywords: Discourse; education; South Africa; Nelson Mandela; human rights; social justice; democracy

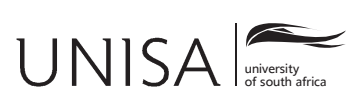

Education as Change www.educationaschange.co.za Volume 20 | Number 1 | 2016 pp. $172-198$

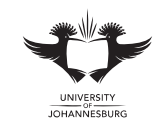

DOI: http://dx.doi.org/10.17159/1947-9417/2016/899 Print ISSN 1682-3206 | Online 1947-9417

(C) 2016 The Authors 
Nelson Mandela, the late father of modern South Africa, has been widely praised for his pursuit of social justice, democracy, equality, and the fulfilment of human rights for all South Africans, but he also has his critics. As scholars are now reassessing his legacy in full in everyday thought and practice, we examine here his impact on education, a sector pivotal to national development and the Millennium Development Goals. As Mandela famously remarked in a 2003 speech at the University of the Witwatersrand, 'education is the most powerful weapon you can use to change the world'. While such optimistic sentiments provide hope to those seeking to build a better future, the stark realities of the present call for a re-examination of Mandela's legacy in the way the government of the Republic of South Africa has approached the education sector. Education is widely seen as essential to advancing development, democracy, and human rights throughout Africa, but twenty years after the end of apartheid, South Africa is still one of the most unequal countries in the world. Historically, its education sector has been used to 'discriminate against people on the grounds of colour alone and against the poor, weak, and the oppressed, instead of being used to throw open the doors of opportunity' (Hartshorne 1999, 2). When Nelson Mandela came to power in 1994, newly democratic South Africa sought to reverse this trend, but the education system still faces many of the same challenges: declines in student enrolment, a large shortage of trained teachers (Van De Berg 2007), racial disparities in examination scores (Fleisch 2008), and low quality mathematics and science education (World Economic Forum 2012, 325). Though hailed as a 'rainbow nation' with the second largest economy on the continent in 2014, it has been feared that South Africa's post-apartheid education system has lost focus, no longer adequately responding to social and economic inequality (Peet 2002; Tikly 2003; Christie 2010).

Addressing this putative transformation, we assess the degree to which social justice, democratisation, and human rights have been pushed aside in public education discourse by analysing annual reports and landmark documents of the Republic of South Africa's national Department of Education. Beginning with a discussion of Nelson Mandela's views on the purpose of education and the historical context in South Africa that has shaped education policy-making over the past two decades, we then examine shifts in official education discourse via quantitative content analysis (QCA). As discussed below, we find education has consistently been framed as critically important for economic development, but emphasis on the role of education in strengthening social justice, human rights, and democracy has declined notably in the twenty-first century.

\section{MANDELA'S PERSPECTIVE ON EDUCATION}

The method we apply to derive Mandela's general views on education stems from Fairclough's $(1995,2)$ 'three-dimensional approach' to critical discourse analysis, 
which examines the content of spoken and written texts, the historical context in which they are situated, and the production, distribution, and consumption of those texts. We rely on discourse analysis of his public speeches and utterances - focusing on those which his own autobiographical works have identified as salient. As a major public figure, his writings and speeches are voluminous. Thus we selected those public statements that seem to us as representative of his general disposition towards education. Our aim was to identify major themes and areas of emphasis that Mandela expressed regarding education that have broad implications for the general direction of education policy, as opposed to a full exploration of all the various nuances in his educational thought and practice and personal experiences. ${ }^{1}$

As Fairclough $(1995,9)$ emphasises, "textual analysis should be combined with analysis of practices of production and consumption'. Thus, we have concentrated on statements of Mandela that have been reproduced in biographical compilations designed to be consumed by the general public as distillations of his thought on various issues. We also situate his assertions within 'particular historical conditions' (ibid, 19) while acknowledging that discourses attributed to Mandela may have been part of a broader intertextual milieu in which 'texts are constituted from other already produced texts' (ibid) whereby often 'the speaker "forgets" that he or she is just the function of a discursive and ideological formation, and thus comes to misrecognize herself as the author of her own discourse' (Eagleton 2007, 196). ${ }^{2}$ We also aimed to situate Mandela's views on education within the context of the larger twentiethcentury South African social movement struggling for freedom and democracy. As opposed to advocating an individual-centred view of history, we see Mandela as part of a broader social movement which heavily influenced his own discourse. We thus impart social meaning to Mandela's discourse on education by recognising that it depended 'on the concrete context of utterance' (Eagleton 2007, 194).

The context in which Mandela's earliest views on education developed was under the unequal and racially-based system of apartheid. Prior to democratisation in 1994, South Africa was ruled for nearly five decades by the Afrikaner National Party whose racist apartheid policy segmented South Africa into inequitable 'African', 'coloured', 'Indian' and 'European' areas. Overtly institutionalising a 'divide and conquer' mentality, the prevailing hierarchy propelled white dominance over non-whites (Anderson 2002). Systematic denial of rights to movement, free speech, political organisation, and citizenship (Evans 1997; Seidman 1999; Seekings \& Nattrass 2005) entrenched, normalised, and legitimised an oppressive relationship between the white minority and African majority (Abdi 2002). Under this system, first formalised in the 1953 Bantu Education Act, segregation and racial paternalism characterised education. Propagating the idea that the 'Bantu' (Black African) mind was different from supposedly superior white minds, the Act justified separate schools and a distinct curriculum segmented along racial lines (Seidman 1999). Public spending per child by the apartheid state was as much as eight times higher 
for white education than for black education (Weber 2002a), and education for blacks was intentionally limited to inhibit their politicisation (Brewer 1986). Ultimately, the normative objective was to teach blacks 'to know their place as suppliers of cheap labour' (Weber 2002b, 280).

Confronting the dominant racialising discourse of the apartheid era, it is clear from Nelson Mandela's earliest speeches and writings, that he strongly opposed educational segregation on racial grounds. Rather, he viewed education as playing a crucial role in imparting character and underpinning democracy. In 1948, he was a co-author of the African National Congress (ANC) Youth League Basic Policy Document stressing the importance of education in giving pupils 'a high sense of moral and ethical values' and preparing them 'for a full and responsible citizenship in a democratic society' (Mandela 1990, 23). Under Mandela's urging, at the 1949 ANC National Conference, the party's 'Programme of Action' stressed the importance of education for the economic development of black Africans through the

Establishment of national centres of education for the purpose of training and educating African youth and provision of large-scale scholarships tenable in various overseas countries ... raising the standard of Africans in the commercial, industrial and other enterprises and workers in the workers' organisations by means of providing a common educational forum wherein intellectuals, peasants and workers participate for the common good. (Mandela 1991, 29)

As these passages illustrate, Mandela held that the function of education is to serve the well-being of the nation and peoples from all racial and class backgrounds, and he pragmatically saw two primary channels by which education would promote these goals: a) economic advance through imparting training and skills; and b) the fostering of social justice, human rights, and democracy through diverse forms of educational delivery and a progressive curriculum shaping values and character.

Mandela further elaborated on these points to the ANC (Transvaal) Congress in 1953 in reaction to the Bantu Education Act of the same year. He squarely rejected the apartheid ideology of racial hierarchy and stratification:

You must defend the right of African parents to decide the kind of education that shall be given to their children. Teach the children that Africans are not one iota inferior to Europeans. Establish your own community schools where the right kind of education will be given to our children. If it becomes dangerous or impossible to have these alternative schools, then again you must make every home, every shack or rickety structure a centre of learning for our children. Never surrender to the inhuman and barbaric theories of Verwoerd. (Mandela 1991, 29)

Similarly, in 1957, when the apartheid government put forth the Separate Universities Education Bill, Mandela saw it as an attack on the well-being of the entire nation and non-Europeans in particular: 
The type of universities the bill envisages will be nothing more than tribal colleges, controlled by party politicians and based upon the doctrine of the perpetual supremacy of the whites over the blacks. Such colleges would be used by the government to enforce its political ideology at a university level ... Not free inquiry but indoctrination is their purpose, and the education they will give will not be directed towards the unleashing of the creative potentialities of the people but towards preparing them for perpetual mental and spiritual servitude to the whites ... For centuries, universities have served as centres for the dissemination of learning and knowledge to all students irrespective of their colour or creed. In multiracial societies they serve as centres for the development of the cultural and spiritual aspects of the life of the people. Once the bill is passed, our universities can no longer serve as centres for the development of the cultural and spiritual aspects of the entire nation. (Mandela 1990, 65-67)

Looking back at his personal story, Mandela had been impressed by the impact and agency of power by educated black Africans, even as a young boy at a primary school in Mqhekezweni witnessing the impact of missionary education in creating a new level of African elite (Meredith 2010, 9). After completing his primary and secondary education, Mandela was sent to the only university in the country accepting non-white students (African, coloured and Indian), Fort Hare University near Alice, Eastern Cape (Mandela 1994, 62). He studied for a Bachelor of Arts degree, taking courses in English, anthropology, politics, native administration and Roman Dutch law (Meredith 2010, 18). Mandela would not complete his bachelor degree at Fort Hare, being involved in a judicial conflict at the university regarding the election process of the Student Representative Council. However, after having moved to Johannesburg from Alice, Mandela resumed his tertiary education through a University of South Africa correspondence course and passed his exams in 1934 (Sampson 2011, 34).

With his BA degree completed, Mandela began his law studies at the University of the Witwatersrand as the only black African student (Mandela 1994, 127). He then joined the African National Congress (Mandela 1994, 136). Ultimately, Mandela's politics occupied his time to the point that he failed the final year of his law programme three times, and was denied the degree in December 1949 (Sampson $2011,35)$. However, he did eventually go on to pass his qualification exams to practice law in 1953.

Nelson Mandela would not resume his education until his imprisonment as a political prisoner in 1962. Over the next three decades, from 1962 to 1990, Mandela did not make any major new pronouncements regarding education, but took time to further the education of fellow prisoners, as well as his own education. Under his guidance, Robben Island became a sort of informal 'university', as prisoners began to learn from each other, teaching topics as basic as literacy and numeracy to the political education of the resistance movement (Buntman 2003, 64). More formal, academic education was also encouraged by fellow prisoners, and facilitated through correspondence courses at institutions like the University of South Africa 
(Bady 2014, 108). As a result, Robben Island transformed the lives of many, with liberating ideologies, skills, and degrees.

Like his fellow prisoners, Mandela similarly recommenced his correspondence courses, this time for a Bachelor of Laws degree (Mandela 1994, 463). When transferred from Pretoria to the prison on Robben Island in 1964, Mandela began teaching himself Afrikaans and other subjects, as well as working on his law degree at night. This was a crucial period not only for his own personal learning, but also in terms of contributing to the notion of Robben Island as a university - a collective praxis - and engaging in 'critical reflection' involving 'the deliberate uncovering and challenging of assumptions concerning power and the perpetuation of hegemony' (Brookfield 2008, 96).

Mandela once again spoke about the importance of education immediately after his release from prison by President F.W. de Klerk in 1990. In campaign speeches in the early 1990s, Mandela reiterated that education should serve racial harmony, democracy, and the well-being of the entire nation and he advocated integration of the country's segregated and unequal education systems. For example, in a 1993 speech commemorating the $17^{\text {th }}$ anniversary of the 1976 Soweto Uprising he proclaimed 'education is very crucial for your future as it will enable you to better serve your communities and our country during the difficult period of reconstruction' (Mandela 2003, 241). A year later, Mandela was elected president and by 1996, South Africa's new Constitution included unprecedented support for human rights, political enfranchisement, civil liberties, commitment to national unity, and prohibitions against discrimination according to any identity (Berger 2003). Within this vein, the Constitution also guaranteed a positive right to education in Chapter 2, Section 29(1), stating 'everyone has the right, a) to a basic education, including adult basic education; and b) to further education, which the state, through reasonable measures, must make progressively available and accessible'.

As president, Mandela tried to balance the goals of redressing inequities and improving social welfare while pursuing cooperation and peace (Weber 2002b). Therefore, despite the magnitude of educational deprivation in the country among non-whites, radical restructuring was eschewed in favour of moderate reforms (Soudien 2007). Emphasis on gradual change while retaining harmony and pursuing economic development was evident in Mandela's 1997 speech at the Education Africa Presidential and Premier Education Awards:

The power of education extends beyond the development of skills we need for economic success. It can contribute to nation-building and reconciliation. Our previous system emphasized the physical and other differences of South Africans with devastating effects. We are steadily but surely introducing education that enables our children to exploit their similarities and common goals, while appreciating the strength in their diversity ... Let us join hands, as government, business, NGOs and communities, let us work together to educate our nation! (Mandela 2003, 252) 
Likewise, in one of Mandela's last major pronouncements on education before stepping down as president, he reiterated his long-standing emphases of education upholding both the economy and democracy. These remarks made in 1998 at the opening of the Dalindyebo Senior Secondary School in Qunu highlight Mandela's approach to maintaining diversity in schooling both in types of providers and sources of educational financing:

We can only make a better life for all South Africans if our young people get the skills and the training that we need to make our economy grow and make our democracy work. That is why our new education policy makes general education compulsory for all children ... If our education system is to produce the capable, skilled and empowered people who can turn South Africa into the just and prosperous nation of our dreams, we must overcome the years of neglect which left most of our children without proper facilities for their education ... Partnership between government, the private sector and communities is critical in the development of our country. No one sector on its own, least of all government can succeed in ensuring that we do improve the quality of life of our people. BP South Africa - and the local BP dealers in Umtata who have also contributed - have set a shining example of such partnership ... You should also know that BP is not alone in our private sector, in joining hands with government and communities. Across our land there are clinics and schools which communities now have thanks to such projects. This is part of the investment back into our communities, especially those which are poor, which is needed to eradicate the legacy of apartheid and build the future of our country. (Mandela 2003, 255-256)

\section{ASSESSING MANDELA'S LEGACY IN EDUCATION DISCOURSE}

Our assessment of the Mandela legacy in education discourse concentrates on the extent to which official education discourse still centres upon major ideas associated with Mandela. Mandela's eagerness to support education for poor and disadvantaged children is evident in the fact that while president, 'he donated one-third of his salary to those children through the Nelson Mandela Children's Fund' (McKell 2015) which may be well-remembered and cherished, but our focus here is on whether his views of the role of education in society continue to remain at the forefront of discussions over education policy. From the above passages covering the period from Mandela's early political activism to the end of his presidential term, we have identified two prominent strands in Mandela's education thought. The first relates to social justice with emphasis on the positive contributions of education to advancing racial harmony, democracy, redressing injustice, and upholding human rights. The second strand involves a pragmatic focus on economic benefits made possible through education both at the individual level, whereby skills and training enhance employment opportunities, and at the national level, as an educated population contributes to national prosperity. 
We now examine to what extent official South African education discourse has maintained these twin emphases over the past two decades. Our focus here is on broader shifts in public education discourse rather than on specific education policies. We believe that discourse is an important object of investigation in itself because it plays a significant role in shaping the very terms and referents that policy-makers resort to when making and re-shaping policies (Foucault 1972; Boden \& Nedeva 2010; Shahjahan 2011). Discourses, like ideologies, are powerful because they decontest concepts by defining terms in a certain way to the exclusion of other possible meanings. In this sense, they structure "which conceptual combinations are available to be applied to the understanding and shaping of the political world' (Freeden 1996, 551). Moreover, participants in a discourse may deliberately deploy concepts in an effort to shape the thoughts and actions of a broad audience of intended consumers while many of these concepts themselves are actually inherited unconsciously from a specific historical and social milieu (Freeden 2003, 11). Discourses and the ideological strands embedded within a discourse impact public policy because they can a) change how people perceive an issue and the language used to describe it, b) frame agendas for action, and c) alter how groups perceive their interests (Jolly, Emmerij \& Weiss 2009, 42).

In our view, discourse is both an agent and a structure in constant flux. It is shaped by broader political, economic, and social contexts while simultaneously shaping them. Whereas some theorists like Foucault (1972) see reality as constituted by discourse, we take an intermediate position that discourse significantly shapes but does not in itself constitute reality, as some (but not all) interests appear to truly exist prior to discursive formations. As Eagleton $(2007,214)$ remarks, "why, in any case, should someone become a socialist, feminist or anti-racist, if these political interests are in no sense a response to the way society is? ... Are we being asked to believe that the reason some people vote Conservative is not because they are afraid a Labour government might nationalise their property, but that their regard for their property is created by the act of voting Conservative?'.

Since discourses cannot be fully separated from social infrastructures and institutions (Eagleton 2007, 199), there will always be significant ideological effects present within a discourse in the explicit and implicit messages of a text. As Fairclough $(1995,5)$ points out, 'what is absent from a text is often just as significant', therefore it is worthwhile to pursue a comparative form of textual analysis 'which allows for a systematic focus upon absences'. As Foucault $(1972,25)$ notes, 'the manifest discourse, therefore, is really no more than the repressive presence of what it does not say'. As the meaning of a text always varies 'from one communicative situation to the next' (Eagleton 2007, 194), textual analysis should also include 'analysis of the texture of texts, their form and organisation, and not just commentaries on the "content" of texts which ignore texture' (Fairclough 1995, 4).

Our assessment of Mandela's legacy in official education policy discourse therefore employs content analysis of South African Department of Education 
documents over the period of 1990 to 2012. Leveraging the advantages of a mixed methods research design we combine two approaches (Cresswell 2009). The first method, qualitative discourse analysis, identifies dominant narrative themes in particular texts and changing textual emphases and justifications over time. As Alexander George $(1959,23)$ points out:

In order to make valid inference of intended meaning in each specific instance of communication, the investigator also takes into account the situational and behavioural contexts of the communications ... to determine which of the possible meanings of the words in question the speaker intends to convey in the instance at hand and the precise shading of his intended meaning.

We then apply a second method, quantitative content analysis (QCA). This allows for the classification and measurement of content, particularly keywords indicative of and derived from a certain ideology or perspective, in a precise and numerical form (Kaplan \& Goldsen 1949). This enables us to examine the relative frequency of words, concepts, and topics as an indication of the degree to which they reflect issues of greater or lesser emphasis in a text (Starosta 1984). Several strengths of this procedure are reduced interpretative burden in coding and a high degree of transparency, reproducibility, and reliability in inter-coder and intra-coder agreement (Weber 1990).

Methodologically, the integration of these two forms of content analysis permits a systematic evaluation of a document's ideational content as has been applied elsewhere to study the education and development policy discourse of organisations like the World Bank (Joshi \& Smith 2012; Joshi \& O’Dell 2013). Scholars have also applied content analysis to studies of South African education. For example, Weber (2002a) conducted a qualitative review of education department documents concluding that the South African Schools Act (SASA) of 1996 was the beginning of a transition towards decentralisation, privatisation, and other manifestations of neo-liberalism in the education sector. Tikly $(2011,88)$ similarly applied content analysis to the 2009 Educational Roadmap: Policy Brief \#9, finding evidence of 'a further shift in South African education policy towards the take up of human capital themes including more recent trends linking the quality of education with economic growth'.

Our aim here is to build off these previous studies to assess broader discursive shifts over time within South African ministries of education by analysing the annual reports of those education departments tasked with administering basic (primary and secondary level) education to the majority of the population. We chose annual reports as they are released almost every year. This permits us to capture the timing of discursive changes not possible when examining only a single document or a more limited time-period. These reports are also publicly available summary statements serving as useful indications of what the education ministry prioritises and wants to communicate to the public. Because annual reports follow roughly the 
same format from year to year, changes in emphasis and rhetoric become readily apparent. Annual reports also serve as a particular semiotic form or genre of text that is homogeneous in nature. As Fairclough $(1995,8)$ notes: 'A relatively homogeneous text is relatively consistent semantically and formally - a consistent construction of relations between text producer and audience through the text for instance may be partly realized through consistencies of modality'.

We covered seven annual reports issued in three eras of contemporary South African history: late apartheid, liberation, and post-liberation. We examined the 1990 annual report from the Department of Education and Training (1991) issued while F.W. de Klerk was still president; the first two annual reports, 1994/95 and 1996, issued by the Department of Education (DoE 1995a; 1996) under President Nelson Mandela; one report each from the beginning and end of President Thabo Mbeki's term, 2001/02 and 2007/08 (DoE 2002; 2008a); the first report at the start of Jacob Zuma's presidency, 2008/09 (DoE 2009), as well as the more recently issued 2011/2012 report from the Department of Basic Education (2012). Additionally, we analysed the rhetoric and central themes of four important landmark policy documents in South Africa impacting education over this period: the Reconstruction and Development Programme (RDP) (RSA 1994); the South African Schools Act (SASA) (DoE 1996); the Growth, Employment and Redistribution (GEAR) policy (RSA 1996); and the National Qualifications Framework (NQF) Act (DoE 2008b). Each of these documents reflects major pronouncements or policy shifts impacting educational governance that have been crucial in setting the tone for the government's overall national education policy framework.

\section{QUALITATIVE ANALYSIS}

Our qualitative discourse analysis begins with the late apartheid era 1990 annual report issued by the Department of Education and Training (DET) several years prior to Mandela's election to the presidency. Official educational thought and practice at the time emphasised segregation and was opposed to equalising educational resources and opportunities to all sections of the population. Although the DET (1991, xxvi) was 'responsible for the provision of education to Black people', its report blamed unsatisfactory educational delivery not on the department or the government, but on [black] Africans themselves, stating for example, 'it is all the more tragic that the Department had to spend so much precious time and energy attempting to reduce unrest, and to disciplining pupils and staff' (DET 1991, 6). Likewise, student unrest, dating back to the Soweto Uprisings of 1976, was not portrayed as reflecting genuine demands by black students for an adequate education. Rather, black students were depicted as troublesome pawns and 'victims of adults' power struggles and political aspirations ... pupils and teachers who behave illegally will be dealt with firmly' (DET 1991, 7). In the same vein, the report dismissed the idea that useful 
recommendations for improving the situation had been put forth by the community, blaming black society for producing no 'meaningful proposals' (DET 1991, 8).

The 1990 report also rejected the idea of universal education for the sake of efficiency, stating that students "who do not really stand a chance of being successfully educated in certain standards are overcrowding classrooms' (DET 1991, 12). The DET $(1991,10)$ also claimed it was 'incapable at this stage of justifying greater government spending on education, [so] the existing resources must simply be better utilized'. Rather than guaranteeing children an education, the report shifts this duty elsewhere: 'It is in principle a parental responsibility to provide children with an education' (DET 1991, 18). Likewise, the task of improving educational quality, particularly in maths and physical sciences, was assigned to the private sector, releasing the state from the 'burden' of teaching hard sciences to black students.

As apartheid gave way to democracy, however, a monumental shift in education discourse becomes highly visible. The first major policy document of Mandela's ANC government, the 1994 Reconstruction and Development Programme (RDP), devoted an entire chapter titled 'Developing Our Human Resources' to schooling; it condemned the "fragmentation along racial and ethnic lines, and [saturation] of racist and sexist ideology and educational doctrines of apartheid' whereby 'the majority of the population was neglected, distorted and suppressed' (RSA 1994, sec. 3.1.1). The document strongly criticises the fact that 'vast disparities exist between black and white provision, and large numbers of people - in particular, adults (and more especially women), out-of-school youth, and children of pre-school age - have little or no access to education and training' (RSA 1994, sec. 3.1.1).

The RDP also mentions the newly 'democratic government' as a positive influence and proposes a progressive focus within education to advance socioeconomic development and equitable change;

The RDP integrates growth, development, reconstruction and redistribution into a unified Programme. The key to this link is an infrastructural programme that will provide access to modern and effective services like electricity, water, telecommunications, transport, health, education and training for all our people. This programme will both meet basic needs and open up previously suppressed economic and human potential in urban and rural areas. (RSA 1994, 6, italics added)

Overall, the discourse of the RDP repeatedly invokes images of progress, redress, and the rights of South African learners with considerable emphasis on self-development, 'alongside ensuring that basic needs are met, the society is democratised and the economy grows' (RSA 1994, sec 3.2.1). The document also treats education as a 'public good', beneficial to both the individual and the community, available to all, driven by a strong state mechanism, and equitable according to need (Ball \& Youdell 2007). The document suggests the new ANC government planned to pursue strong investment by the state in public education and improving social opportunities 
through equal access to quality education, features common to both developmental liberal democracies and social democracies (Joshi \& Navlakha 2010; Joshi 2013).

The first annual report of the newly renamed and unified Department of Education (DoE) (1994/95) under President Mandela mirrors this discourse. The first lines of its introduction, which 'happily consigns to the demolition heap the bitter legacy of apartheid education' (DoE 1995a, 10), call for education to foster a unified nation and a democratic government with as many invested stakeholders feeling heard as possible to maintain stability and legitimacy. The intention was to reverse apartheid's legacy and to 'bring redress, establish quality, open the doors of opportunity, enable a true culture of learning and teaching to take root, strive for ever-higher levels of performance and achieve all this cost-effectively and within sustainable budgetary limits' (DoE 1995a, 9). While there was a clear sense of the difficult tasks awaiting the department, the new goal for education policy was lofty: to 'be just and equitable; be open and accessible; redress past inequalities; improve quality of delivery; encourage independent and critical thought; and celebrate the diversity of cultures, languages and religious traditions' (DoE 1995a, 19).

The report also expresses the need to greatly expand the department's reach; 'transformation of the education and training system involves moving from the provision of education for an elite to education for all, ensuring that all people young and old, men and women, urban and rural dwellers - have access to education and training on a lifelong basis' (DoE 1995a, 10, italics added). The report's discourse also closely resembles what Rioux and Pinto (2010) identify as a human-rights based approach to education including explicit attempts to integrate language alluding to cultural concerns, youth interests, and those marginalised by race, gender, ability, or age. Reflecting Mandela's long-standing vision of education fostering a unified nation, education was depicted as a crucial means for 'the creation of a common citizenship and nationhood, so leading to the eradication of divisions based on race, ethnicity, creed, colour and gender' and 'building a peaceful, prosperous and democratic South Africa' (DoE 1995a, 10).

The 1996 annual report issued the following year retains many of these same emphases while acknowledging the difficulties of establishing a fully centralised education department, bringing together previously disparate departments cohesively and incorporating as many stakeholders as possible. The Minister of Education, S.M.E. Bengu, directly stated the department's intentions:

I wish to assure all South Africans that the new education system is being professionally planned and carried out, democratically governed, and effectively managed; that the structures and strategies developed will be such as to enhance quality; and that the resources will be equitably distributed over the population as a whole. (DoE 1997, 18, italics added)

The report also defends the 1996 South African Schools Act (SASA), discussed below, which aimed to increase institutional access to education as compatible with a human rights-based approach to education. In discussing programmes and curriculum in its 
section on 'Further Education and Training' (referring to secondary and transitional education), the primary focus is to 'prepare learners for the workplace, not only in the traditional formal sector, but also to develop entrepreneurial skills among learners' (DoE 1997, 22). Here, emphasis on entry and competitiveness in the market reflects economic motives for expanding education, one that Mandela had likewise championed back in the 1940s and 1950s. Overall the report reflects Mandela's twin emphases on education for social justice and economic development. On the one hand, it stresses progressive redress of apartheid, human rights, the creation of stable governance, and the rule of law. On the other hand, it frames education as crucial for enriching the national economy.

We also examined two landmark educational documents issued that year. The first, the South African Schools Act (SASA) of 1996 was one of the most comprehensive reforms in the early years of ANC rule. The SASA, which 'intended to democratize education and school practice' (Duma 2009, 135), gave a significant amount of autonomy and power to local school governance, particularly parentparticipant groups. Though currently educational decentralisation is frequently associated with neo-liberalism, Mandela's government was arguably guided by the idea that decentralisation would facilitate educational democratisation. As mentioned earlier, Mandela $(1991,29)$ had always felt strongly that African parents should be able 'to decide the kind of education that shall be given to their children'. Though the SASA has met considerable criticism by proponents of centralisation, it has also been considered the 'government's most specific plan to date for equitable funding of public schools' (Stenvoll-Wells \& Sayed 2012, 100).

A second document, the Growth, Employment and Redistribution (GEAR) policy of 1996, however, diverges from the previously discussed documents. GEAR displays more of a neo-liberal discourse, addressing government policies in all sectors including education as a 'key determinant of long-run economic performance' (RSA 1996, 15). In particular, GEAR called for mechanisms such as decentralisation, expanded qualifications testing, increased private sector involvement, and programmes to 'strengthen the relationship between educational institutions and industry' (RSA 1996,13). Whereas the early education discourse of Mandela and his ANC government stood on two legs, one representing social justice and human rights, and the other representing economic development, GEAR focused almost exclusively on the latter, foreshadowing the imminent decline of the former.

We then turn to the 2001/02 DoE annual report, the first one issued under President Thabo Mbeki, Mandela's appointed successor. Consistent with a human rights-based approach to education, a large section of the report highlights equity for the most marginalised and redressing of past injustices through the expansion of adult literacy programmes. Education is treated here as a multiplier of other human rights; as access to education for adults is guaranteed, other rights and liberties are better understood, demanded, and exercised. The report also acknowledges the country's 
HIV/Aids epidemic and the DoE's responsibility to respond to it. As in the Mandela era reports, there is much emphasis on the South African government creating a 'nation' and the idea that 'education is not only pivotal to economic prosperity but is an important driver to achieve the priorities of government' (DoE 2002, 8). The report also discusses the need for infrastructure, especially buildings, water, and sanitation in rural areas. However, most references to infrastructure are within the context of school safety, along with brief mentions of the serious issues of sexual and drug abuse. Overall there is admittedly less focus on human rights than in the Mandela era reports, as the most prominent theme in the report is nation-building and national cohesion.

Several years later, in the last DoE (2008a) annual report issued during the Mbeki presidency, we found a further decline in human rights-oriented discourse. While the department's primary mandate was still defined by the constitutional right to education and various commitments to education in international protocols, there was a strong emphasis on the need for quality service within educational delivery and support from the private sector and international development agencies as partners, something not mentioned in previous reports we analysed. In the report's 'Message from the Minister', there is a continued sense of education's role in nationbuilding and the department's aim of 'focusing on promoting civil participation and responsibility amongst young people, evoking national pride and unity, as well as promoting social cohesion and nation-building' (DoE 2008a, 10). Other priorities included increasing the number of 'no-fee' public schools as well as expanding nutrition programmes and improving teaching and learning within disadvantaged communities, particularly rural ones. A need to spend more money on the teaching of mathematics and sciences was also identified to 'respond to the socio-economic needs of this country' (DoE 2008a, 13). Although not as strong as in the immediate post-liberation period, we do see a continuation in this report of the education for social justice theme evoked by Mandela and attempts to directly link this discourse with policy reforms.

We also studied the discourse of the National Qualifications Framework (NQF) Act, a landmark education document issued in 2008. The NQF was an updated version of the 1995 Qualifications Authority Act, a comprehensive outcomes-based educational structure which aimed to enhance learning achievement, expand mobility within education, and improve the quality of education to 'accelerate the redress of past unfair discrimination in education, training and employment opportunities; and thereby contribute to the full personal development of each learner and the social and economic development of the nation at large' (DoE 1995b, 2). The NQF maintained the tradition of Mandela's education discourse concerning empowerment, democratisation and human rights. For example, the notion of a democratic model of education was salient in the Act; it emphasised the inclusion of various educational constituencies such as teachers, professors, adult learners, special needs students, 
and groups previously unrepresented in apartheid educational governance (De Clerc 2008). The NQF also reiterated the objective of education to support 'the full personal development of each learner and the social and economic development of the nation at large' (DoE 2008a, 6).

At the same time, the NQF increasingly reflected economic motivations behind education as its outcomes-based education policies emphasised competitive testing and preparing students for the workplace; 'learners ... are more inclined to improve their skills and knowledge, as such improvements increase their employment opportunities ... [and] enhance the functional and intellectual capability of the nation, thereby increasing our chances for success in the global community' (DoE 2008a, 13). The NQF also foreshadowed the DoE's restructuring the following year into two separate ministries, a Department of Basic Education (DBE) and a Department of Higher Education and Training (DHET). The 2008 NQF conveys the sense that the government placed a greater priority on economic goals than fostering a human rights-oriented approach to education, and several authors have suggested that the overt presence of market concerns in the report were consonant with an increasing move towards neo-liberalism, including the importation of techniques and recommendations from the corporate sector to drive South African education (Verger, Novelli \& Altinyelken 2012).

We then examined two reports issued under President Jacob Zuma amidst increasing discussion of South Africa's potential to become a democratic 'developmental state' as a strategy to achieve both the Millennium Development Goals and sustained rapid economic growth (Joshi 2011; 2012). The 2008/09 report jointly issued by DBE and DHET iterated the importance of establishing the rule of law and government legitimacy through legislative mandates and creating 'a framework for transformation in education and training' (DoE 2009, 15). The report advocates substantial financial investments into education, 'so as to expand skills and capacity in order to support economic growth and global competitiveness ... [and to] educate and train professionals who would be able to respond to the socioeconomic needs of the country' (DoE 2009, 11). The section containing a message from the two education ministers discusses the need to deal with unsafe environments in schools, illiteracy, infrastructure, and remedial adult education. A large portion of the ministers' message focuses on the economic benefits of education, but there is also a discussion of the relationship between the department and UNESCO and how better to integrate their ideals and practices.

Lastly, the 2011/2012 DBE annual report contains a similar discourse. The report emphasises values of excellence, teamwork, learning, innovation, and assessment, while conveying a defensive tone regarding the lack of infrastructure and recent book delivery disasters (DBE 2012, 23). Interestingly, there is also an awkward defence, reminiscent of the 1990 DET report, of half a million students being out of school, with blame placed largely on the age and ability of students. Regarding different 
partners within educational work, the business sector is thanked as a collaborator to the state's work and a historic partnership between the department and organised labour groups to increase the number of stakeholders committed to the quality of basic education is briefly mentioned. The report also expresses qualified pride in certain achievements, such as the lack of organised labour demonstrations, strikes, and accusations of corruption during that fiscal year.

Furthermore, the report mentions the goal of gender equity and, to a lesser extent, socioeconomic status as a determinate of quality and achievement in schooling. However, there is little discussion of racial aspects of educational progress. Instead there is an admittance of the severe quality gap between wealthy regions and former Bantu homelands in rural areas historically dependent on 'subsistence agriculture, animal husbandry and remittances from absent migrant workers in towns or on mines. Such districts probably constitute the majority of education districts in South Africa' (DBE 2012, 35). Lastly, the 2011/12 report does occasionally contain progressive and human rights-oriented rhetoric in line with Mandela's emphasis on education for social justice, but the justification for education is predominately framed in economic terms with an increasing focus on the private sector and standardised testing.

\section{QUANTITATIVE ANALYSIS}

To quantitatively assess the Mandela legacy in official education discourse, we tabulated keyword counts from the above-mentioned education reports. Starting with the social justice frame, we identified relevant keywords and counted their frequency as a percentage of all words in each document. As shown in Figure 1 below, during the first half of Mandela's presidency between 1994 and 1996, social justice-oriented language based on the idea of pursuing 'equality' and atoning for 'unequal' conditions and 'inequality' featured prominently in official education discourse. Such words were heavily emphasised in the RDP, SASA, and 1994-95 annual report (AR). However, their usage declined significantly during the 2000s and only slightly increased after Jacob Zuma took office. The word 'democracy' follows a similar trend, experiencing a major decline after having been mentioned repeatedly in the RDP and 1994-95 annual report as shown in Figure 2. This pattern is basically the same for the terms 'empower' and 'redress', which along with mention of 'apartheid' were major components of official education discourse in the first half of Mandela's presidency (between 1994 and 1996) but which have since dropped off precipitously, though 'redress' reappears as an important concept in the 2008 NQF (See Figure 3). In summary, the framing of education within a social justice discourse is not nearly as strong today as when Mandela first became president. 


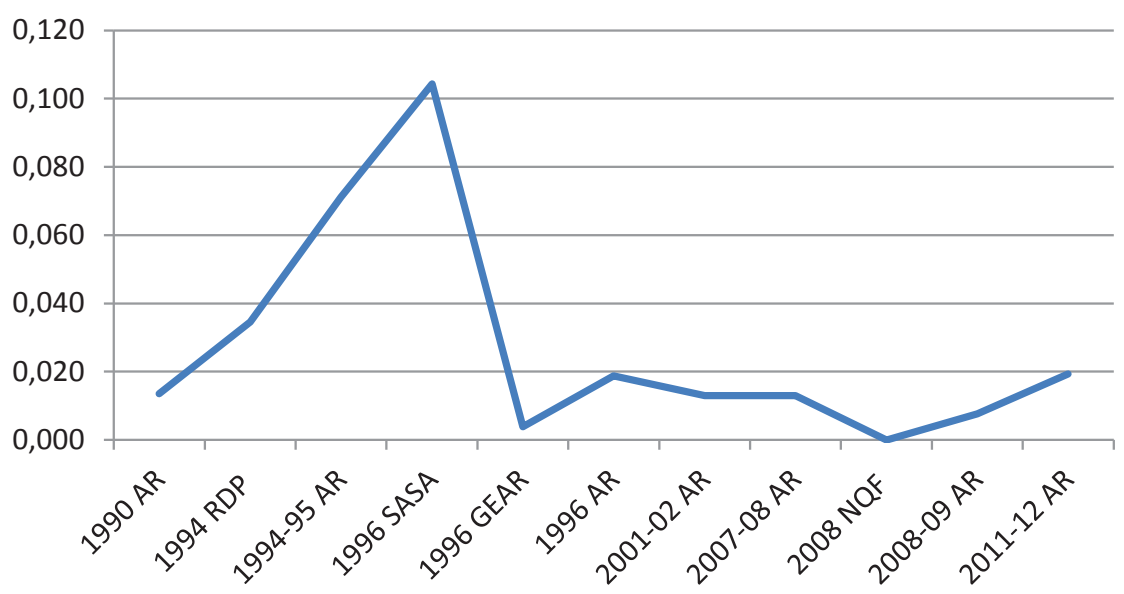

Figure 1: Frequency of the word 'equal' in education reports

*The figure represents the frequency of the term 'equal' including words such as 'unequal' and 'inequality' as a percentage of all words in these documents.

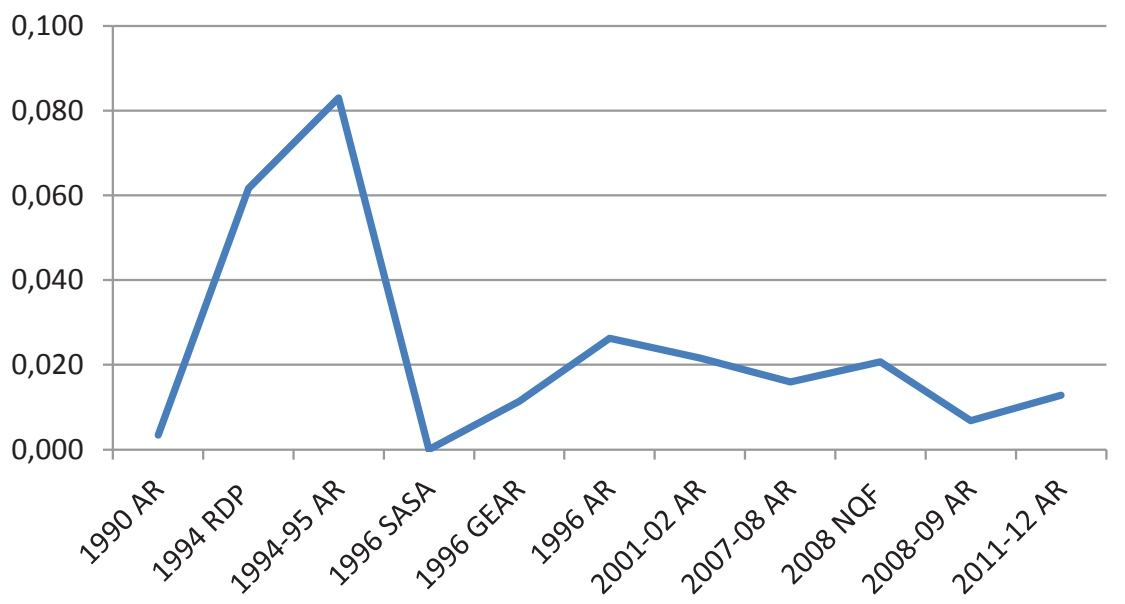

Figure 2: Frequency of the word 'democracy' in education reports

*The figure represents the frequency of the term 'democracy' including words that begin with 'democra' as a percentage of all words in these documents. 


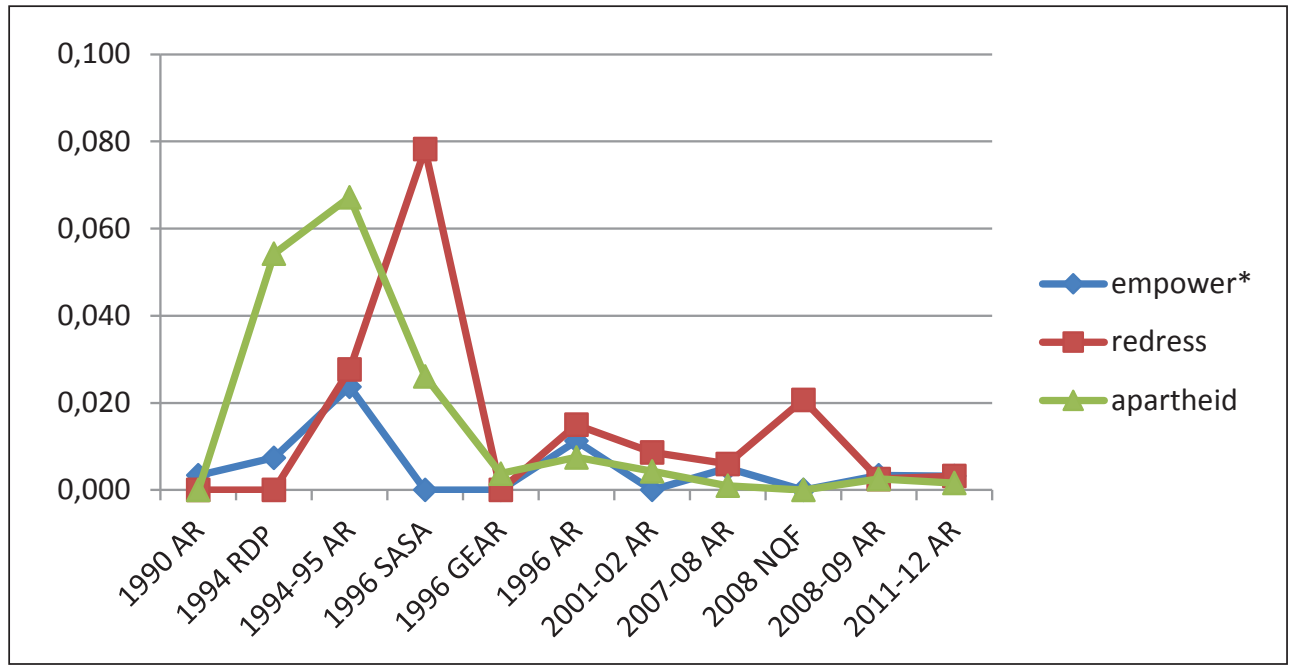

Figure 3: Frequency of the words 'empower', 'redress' and 'apartheid' in education reports

*The figure represents the frequency of the terms 'redress', 'apartheid', and 'empower' including words such as 'empowering' and 'empowerment' as a percentage of all words in these documents.

Turning to Mandela's second strand of emphasis concerning the economic benefits of education, we see much greater continuity over time as the reports consistently advocate education as a means to economic development. Relative to social justice themes, this framing has increased over time and we see an increasing use of words like 'capital' and 'assess' in education reports, suggesting a focus on building human capital through the school system and paying more attention to assessing progress in this regard through student and school evaluations. This is clearly evident in Figure 4. Whereas neither 'capital' nor 'assess' feature in the 1994 RDP, the frequency of these two words has increased significantly over time in annual reports and they appeared three times as often in the 2011-12 DBE report as in the 1994-95 DoE report. 


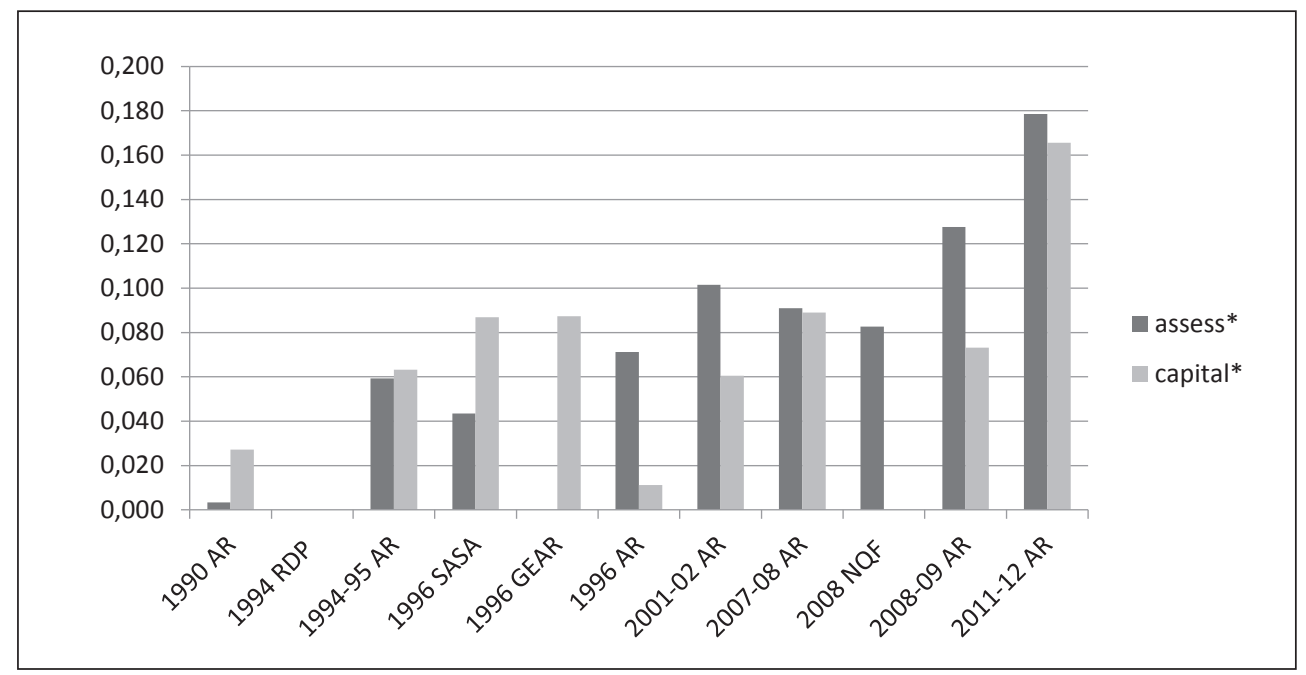

Figure 4: Frequency of the words 'assess' and 'capital' in education reports

*The figure represents the frequency of words containing 'assess' and 'capital' as a percentage of all words in these documents.

Lastly, we examined a set of 'neo-liberal' keywords as some scholars have argued that Mandela planted the seeds for neo-liberalism in the mid-1990s by permitting feepaying schools. For example, Weber (2002b) noted that South Africa experienced a considerable 'shift to the right' shortly after democratisation as reflected in the prominence of neo-liberal economic policies. While this may be true to some degree in terms of policy, we actually did not find many neo-liberal terms frequently appearing in the documents we analysed. While mentions of certain social justiceoriented words like 'redress', 'equality', and 'empower' have declined in education reports over the past two decades, many words heavily associated with neoliberal discourse in countries like the USA and the UK such as 'choice', 'market', 'individual', 'decentralise', and 'freedom' (Beder 2009), have been relatively absent from the ministry's education discourse. These five words rarely appeared in the reports we examined with the lone exception of the 1996 GEAR where the word 'market' appears frequently (see Figure 5). Likewise, as shown in Figure 6, while relative emphasis on the public sector has declined vis-à-vis the private sector in South Africa, since the democratic transition the word 'public' has continued to appear more often than 'private'. 


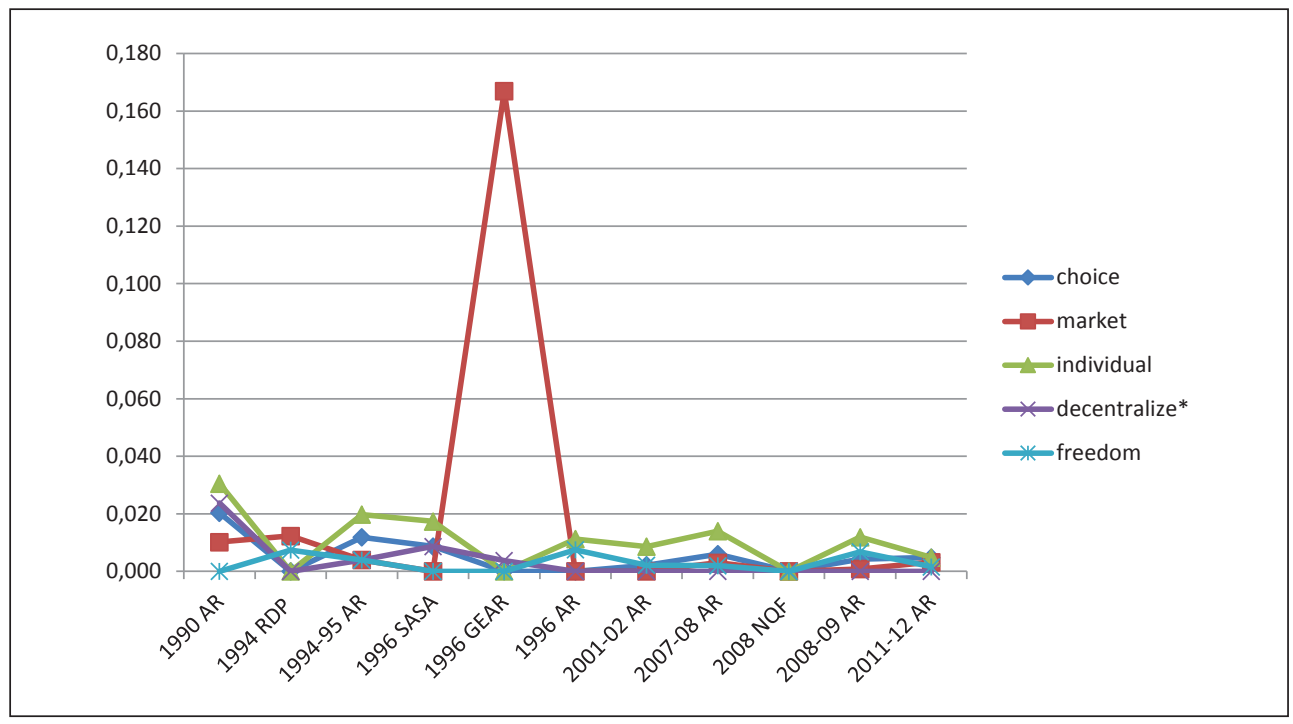

Figure 5: Frequency of neo-liberal keywords in education reports

*The figure represents the frequency of these terms as a percentage of all words in these documents. 'Decentralise' includes words starting with 'decentralis'.

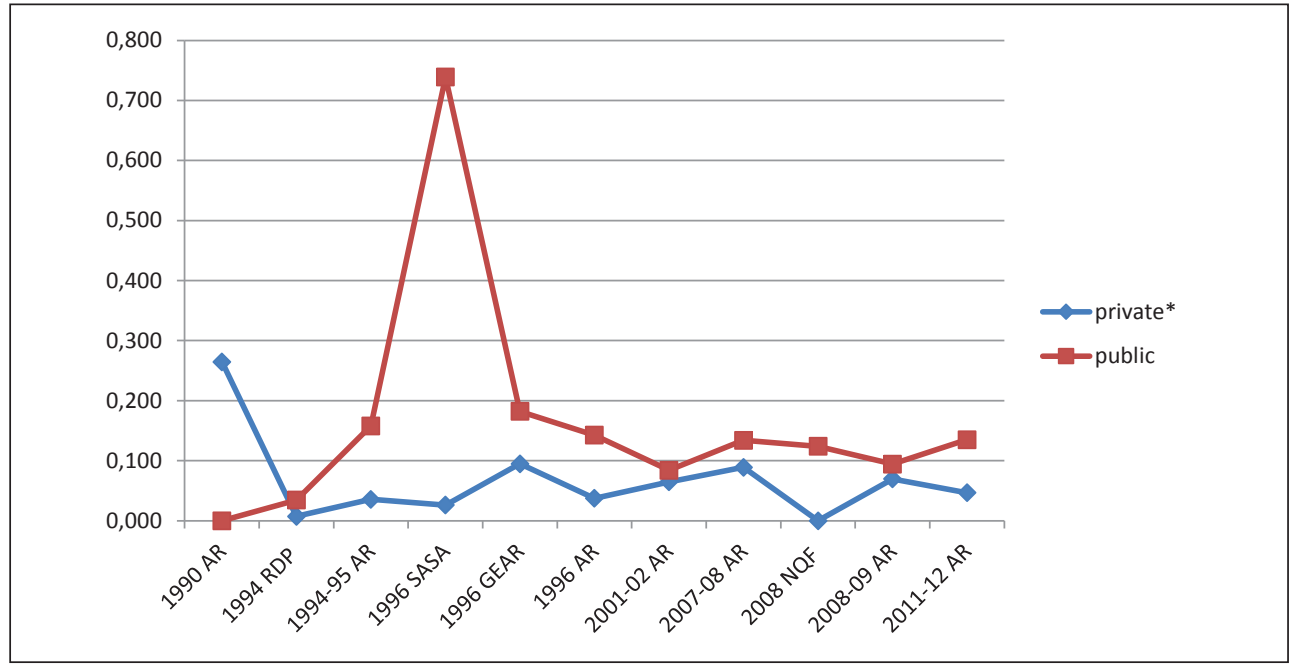

Figure 6: Frequency of the words 'public' and 'private' in education reports

*The figure represents the frequency of these terms as a percentage of all words in these documents. 'Private' includes words starting with the base 'privat'. 


\section{CONCLUSION}

As our qualitative and quantitative content analysis has revealed, after apartheid we saw a transformation in education ministry discourse towards increasing utilisation of a social justice framing with emphasis on empowerment, redressing injustices from apartheid, fostering democracy, and upholding human rights. While the 1990 apartheid era report advocated a (racially) stratified approach to education, our analysis of the 1994/95 and 1996 reports while Mandela was president as well as the RDP and SASA confirm that public education discourse in the early post-apartheid period was framed under human rights rhetoric (Sayed \& Ahmed 2011). In that era, the annual reports' discourse mirrored what Enslin and Pendlebury $(2000,433)$ found to be a 'strong emphasis on rights in post-apartheid education' embodying the principles of non-repression, non-discrimination, and 'outcomes-based education' (Fataar 2006). In particular, curriculum reform, rights discourse, rights consciousness, and democracy were promoted in education based on the idea that

A strong human rights culture should form the basis of South African society in general and the educational environment in particular. Thus these outcomes seek to develop an understanding of the principles of a respect for human rights and their relevance to life. They aim to develop in learners the values, consciousness and competencies that are required for effective participation as responsible citizens of a democratic society. (Enslin \& Pendlebury 2000, 437)

After Mandela left office, with the rise of ANC hegemony in the 2000s, we observed that education discourse shifted more towards economic imperatives and justifications. Foreshadowed by the 1996 GEAR, an education discourse motivated by potential economic benefits coincided with declining social justice rhetoric. More recently, however, as is evident in the $2008 \mathrm{NQF}$ and annual reports since then, we see a slight return to social justice framing with emphasis on redress in official education discourse.

While the longer-term impacts of Mandela's thoughts on educational discourse are still uncertain, in terms of educational outcomes it is obvious that there are still serious gaps between formerly black and formerly white schools in terms of service delivery and quality, along with a persistence of informal racial and class divisions amongst schools as was the case under apartheid. For example, Fiske and Ladd $(2004,81)$ have argued that educational reforms have 'greatly exacerbated differences in the quality of education available to middle class students compared to that available to the majority of poor Blacks'. Nicholas Spaull has come to a similar conclusion:

South Africa is still a tale of two schools: One which is functional, wealthy, and able to educate students; with the other being poor, dysfunctional, and unable to equip students with the necessary numeracy and literacy skills they should be acquiring in primary school ... Without acknowledging and understanding the existing inequalities in South African primary 
education, particularly the extent and nature of those inequalities, the current patterns of poverty and privilege will remain unabated. (Spaull 2013, 444)

While assigning responsibility for current educational deficits is complex, Spreen and Vally $(2006,361)$ see many educational inequalities, especially along racial lines, as a legacy of apartheid within the current social environment, but post-liberation ANC governments have also tended to privilege economic objectives over substantial redress and we found evidence of this in discourse as well. Arguably, much of the party's social justice and human rights rhetoric and sentiment have been limited by budget constraints and pressure to avoid radical change in exchange for stability.

As a proponent of peace and stability after becoming president, Mandela thought it would be pragmatic not to alienate white elites so as to avoid capital flight. Yet, one of the most divisive issues today in South African education remains the continuation of school fees. As significant costs to students and their families, they undermine the ideal of free universal primary education enshrined in the Universal Declaration of Human Rights. As president, Mandela permitted the retention of fee-paying schools, presumably with the aim of not antagonising privileged groups, but in effect this policy has perpetuated class-based and race-based segregation within the education system. As a result, Dieltiens et al. $(2004,6)$ have argued, 'in schooling, the hidden hand of the market has become the veiled regulator of policy. The strain on the education budget and the continued reliance on user fees has seen a yawning gap between rich and poor schools, a policy working for those who can pay for it'.

As of early 2014, however, the current ANC government has sought to reduce the widespread practice of school fees while slightly reviving some of the social justice discourse prominent at the time of democratisation. Expanding no-fee schools to cover the poorest students can be seen as a positive step, but the fact that the government did not take more serious measures to completely eliminate both legal and illegal school fees has been seen by some as signalling a de facto endorsement of practices that widely discriminate against 'price-sensitive groups (e.g. females and the poor)' and which is 'contrary to the rights-based assertions in the constitution and SASA regarding education provisions for all' (Nordstrum 2012, 71, 83). Inattention to guaranteeing all children a quality education in practice has also led the non-profit organisation Equal Education to sue the government in 2012, demanding the DBE and its Minister of Basic Education Angie Motshekga establish minimum norms and standards for school infrastructure. This occurred despite the government's legal obligation to establish minimum norms as outlined in section 5a(1) of the South African Schools Act. While this case indicates that there is space for democratic engagement of civil society with the government of South Africa and the courts have indeed decided in favour of Equal Education requiring the state to establish and maintain compliance with minimum norms and standards (RSA 2013), one might have thought that education would have been a higher priority for the government in the first place. 
In conclusion, through systematic analysis of public education documents we have made an assessment of the Mandela legacy in official education policy discourse. We found Mandela supported formal and informal education both as a means to economic development and as a means to cultivate human rights, democracy, and social justice more broadly. While these twin emphases were both strong during his presidency in the mid-1990s, an economy-oriented discourse in the education sector is much more prominent today than an emphasis on social justice, human rights, and democracy. The social justice and human rights discourse we associate with Mandela during the struggle for freedom and democracy has at this moment gone into decline. Not only has effective ideological de-contestation in favour of social justice not yet occurred, but the recession of social movement pressure has seemingly offered more space for economistic discourses to fill the void. Yet, Nelson Mandela was a leader who saw education as both intrinsically and instrumentally valuable for democracy, nation building, human rights, and solidarity, and not only as a tool for building human capital. A return to such balanced wisdom might indeed be fruitful for the future of South Africa and the rest of the continent. As Mckell reminds us,

symbols of honour bestowed on Mandela are important reflections of our respect and admiration for this great man and what he has achieved. But what is more important is how we in our society reflect his vision in our personal, professional, and public lives; how we commit to building an inclusive society free from all forms of discrimination. That is the true legacy of Nelson Mandela. (McKell 2015)

\section{ENDNOTES}

1. Our approach is influenced by Fairclough $(1995,7)$ for whom 'discourse analysis is analysis of how texts work within sociocultural practice. Such analysis requires attention to textual form, structure and organisation at all levels; phonological, grammatical, lexical (vocabulary) and higher levels of textual organisation in terms of exchange systems (the distribution of speaking turns), structures of argumentation, and generic (activity type) structures'.

2. Though it is beyond the scope of this study, one might further hypothesise that Mandela's words exemplify changing discourses around education and non-racialism within the African National Congress as a whole.

\section{REFERENCES}

Abdi, A.A. 2002. Culture, education and development in South Africa: Historical and contemporary perspectives. Westport: Bergin \& Garvey.

Anderson, G. 2002. Building a people's university in South Africa: Race, compensatory education, and the limits of democratic reform. New York: Peter Lang.

Bady, A. 2014. Robben Island University. Transition 116: 106-119. 
Ball, S. and D. Youdell. 2007. Hidden privatisation in public education. Brussels: Education International.

Beder, S. 2009. This little kiddy went to market: The corporate capture of childhood. London: Pluto Press.

Berger, E. 2003. The right to education under the South African Constitution. Columbia Law Review 103(3): 614-661.

Boden, R. and M. Nedeva. 2010. Employing discourse: Universities and graduate 'employability'. Journal of Education Policy 25(1): 37-54.

Brewer, J.D. 1986. After Soweto: An unfinished journey. New York: Clarendon Press.

Brookfield, S. 2008. Radical questioning on the long walk to freedom: Nelson Mandela and the practice of critical reflection. Adult Education Quarterly 58(2): 95-109.

Buntman, F.L. 2003. Robben Island and prisoner resistance to apartheid. Cambridge: Cambridge University Press.

Christie, P. 2010. The complexity of human rights in global times: The case of the right to education in South Africa. International Journal of Educational Development 30(1): 3-11.

Cresswell, J. 2009. Research design: Qualitative, quantitative, and mixed methods approaches. Thousand Oaks, CA: Sage.

DBE (Department of Basic Education). 2012. Annual report of 2011/12. Pretoria: DBE.

De Clerq, F. 2008. Teacher quality, appraisal and development: The flaws of the IQMS. Perspectives in Education 26(1): 7-18.

Department of Education and Training. 1991. Annual report of 1990. Pretoria: DET.

Dieltiens, V., B. Nzimande, T. Chaka and A. Libhabe. 2004. The democratic challenge: Participation, transformation and education. Quarterly Review of Education and Training 11(2): 3-11.

DoE (Department of Education). 1995a. Annual report of 1994/95. Pretoria: DoE.

DoE. 1995b. Qualifications authority act. Pretoria: DoE.

DoE. 1996. South African schools act. Pretoria: DoE.

DoE. 1997. Annual report of 1996. Pretoria: DoE.

DoE. 2002. Annual report of 2001/02. Pretoria: DoE.

DoE. 2008a. Annual report of 2007/08. Pretoria: DoE.

DoE. 2008b Updated national qualifications framework. Pretoria: DoE.

DoE. 2009. Annual report of 2008/09. Pretoria: DoE.

Duma, M.A. 2009. Rural educators' understanding of the legislations that impact on school practice with specific reference to the Bill of Rights and the South African Schools Act. International Education Studies 2(2): 135-144.

Eagleton, T. 2007. Ideology: An introduction, new and updated edition. London: Verso.

Enslin, P. and S. Pendlebury. 2000. Looking others in the eye: Rights and gender in South African education policy. Journal of Education Policy 15(4): 431-440.

Evans, I. 1997. Bureaucracy and race: Native administration in South Africa. Berkeley, CA: University of California Press. 
Fataar, A. 2006. Policy networks in a recalibrated political terrain: The case of school curriculum policy and politics in South Africa. Journal of Education Policy 21(6): 641-659.

Fairclough, N. 1995. Critical discourse analysis: The critical study of language. New York: Longman.

Fiske, E.B. and H.F. Ladd. 2004. Elusive equity: Education reform in post-apartheid South Africa. Washington: Brookings Institution Press.

Foucault, M. 1972. The archaeology of knowledge and the discourse on language. New York: Pantheon.

Freeden, M. 1996. Ideologies and political theory: A conceptual approach. New York: Oxford University Press.

Freeden, M. 2003. Ideology: A very short introduction. New York: Oxford University Press.

Fleisch, B. 2008. Primary education in crisis: Why South African schoolchildren underachieve in reading and mathematics. Cape Town: Juta.

George, A.L. 1959. Quantitative and qualitative approaches to content analysis. In Trends in content analysis. Edited by I. Sola Pool. Urbana: University of Illinois Press.

Hartshorne, K. 1999. The making of education policy in South Africa. Cape Town: Oxford University Press.

Jolly, R., L. Emmerij, and T.G. Weiss. 2009. UN ideas that changed the world. Bloomington: Indiana University Press.

Joshi, D. and N. Navlakha. 2010. Social democracy in Sweden. Economic and Political Weekly 45(47): 73-80.

Joshi, D. 2011. Multi-party democracies and rapid economic growth: A $21^{\text {st }}$ century breakthrough? Taiwan Journal of Democracy 7(1): 25-46.

Joshi, D. 2012. Varieties of developmental states: Three non-western paths to the Millennium Development Goals. Journal of Developing Societies 28(3): 355-378.

Joshi, D. 2013. The protective and developmental varieties of liberal democracy: A difference in kind or degree? Democratization 20(2): 187-214.

Joshi, D. and R. O’Dell. 2013. Global governance and development ideology: The United Nations and the World Bank on the left-right spectrum. Global Governance 19(2): 249-275.

Joshi, D. and W. Smith. 2012. Education and inequality: Implications of the World Bank's education strategy 2020. In Education strategy in the developing world: Revising the World Bank's education policy. Edited by C.S. Collins and A.W. Wiseman. Bingley: Emerald.

Kaplan, A. and J.M. Goldsen. 1949. The reliability of content analysis categories. In Language of politics: Studies in quantitative semantics. Edited by H.D. Lasswell and N. Leites. New York: George W. Stewart.

Mandela, N. 1990. The struggle is my life. New York: Pathfinder Press.

Mandela, N. 1991. No easy walk to freedom. Johannesburg: Heinemann Publishers.

Mandela, N. 1994. Long walk to freedom, volume I: 1918-1962. New York: Little, Brown and Company.

Mandela, N. 2003. In his own words. New York: Hachette Digital.

Meredith, M. 2010. Mandela: A biography. New York: Public Affairs. 
McKell, L. 2015. Nelson Mandela's legacy more than symbolic. The Star.com. 9 February.

Nordstrum, L.E. 2012. Incentives to exclude: The political economy constraining school fee abolition in South Africa. Journal of Education Policy 27(1): 67-88.

Peet, R. 2002. Ideology, discourse, and the geography of hegemony: From socialist to neoliberal development in post-apartheid South Africa. Antipode 34(1): 54-84.

Rioux, M.H. and P.C. Pinto. 2010. A time for the universal right to education: Back to basics. British Journal of Sociology of Education 31(5): 621-642.

RSA (Republic of South Africa). 1994. Reconstruction and development programme. Pretoria: RSA.

RSA. 1996. Growth, employment and redistribution. Pretoria: RSA.

RSA. 2013. Government gazette no.37081. Pretoria: RSA.

Sampson, A. 2011. Mandela: The authorised biography. London: Harper Collins.

Sayed, Y. and R. Ahmed. 2011. Education quality in post-apartheid South African policy: Balancing equity, diversity, rights and participation. Comparative Education 47(1): 103-118.

Seekings, J. and N. Nattrass. 2005. Class, race, and inequality in South Africa. New Haven: Yale University Press.

Seidman, G. 1999. Is South Africa different? Sociological comparisons and theoretical contributions from the land of apartheid. Annual Review of Sociology 25: 419-40.

Shahjahan, R.A. 2011. Decolonizing the evidence-based education and policy movement: Revealing the colonial vestiges in educational policy, research, and neoliberal reform. Journal of Education Policy 26(2): 181-206.

Soudien, C. 2007. The 'A' factor: Coming to terms with the question of legacy in South African education. International Journal of Educational Development 27(2): 182-193.

Spaull, N. 2013. Poverty and privilege: primary school inequality in South Africa. International Journal of Educational Development 33(5): 436-447.

Spreen, C.A. and S. Vally. 2006. Education rights, education policies and inequality in South Africa. International Journal of Educational Development 26(4): 352-362.

Starosta, W.J. 1984. Qualitative content analysis: A Burkean perspective. In Methods for intercultural communication. Edited by W.B. Gudykunst and Y.Y. Kim. Beverly Hills: Sage.

Stenvoll-Wells, D. and Y. Sayed. 2012. Education decentralization in South Africa and Zimbabwe: The gap between intention and practice. In Global education policy and international development: New agenda, issues and policies. Edited by A. Verger, M. Novelli and H.K. Altinyelken. London: Bloomsbury.

Tikly, L. 2003. Governmentality and the study of education policy in South Africa. Journal of Education Policy 18(2): 161-174.

Tikly, L. 2011. A roadblock to social justice? An analysis and critique of the South African education roadmap. International Journal of Educational Development 31(1): 86-94.

Van der Berg, S. 2007. Apartheid's enduring legacy: Inequalities in education. Journal of African Economies 16(5): 849-880.

Verger, A., M. Novelli, and H.K. Altinyelken, eds. 2012. Global education policy and international development: New agenda, issues and policies. London: Bloomsbury. 
Weber, E. 2002a. An ambiguous, contested terrain: Governance models for a new South African education system. International Journal of Educational Development 22(6): 617-635.

Weber, E. 2002b. Shifting to the right: The evolution of equity in the South African government's developmental and education policies, 1990-1999. Comparative Educational Review 46(3): 261-290.

Weber, R.P. 1990. Basic content analysis. Newbury Park: Sage.

World Economic Forum. 2012. The global competitiveness report 2012-2013: Full data edition. Geneva: World Economic Forum. 